SHORT REPORT

\title{
Toxicity of maduramicin
}

N Sharma, A Bhalla, S Varma, S Jain, S Singh

Emerg Med J 2005;22:880-882. doi: 10.1136/emj.2004.020883

This report documents the first presentation of seven human cases of poisoning with a compound used in poultry feed. The clinical presentation was a toxic polyneuropathy with rhabdomyolysis and acute renal failure. We describe the protracted clinical course of one of these victims along with a tabulated description of the clinical course and relevant laboratory investigations of the others.

M aduramicin is a monoglycoside polyether derived from the fungus Actinomadura rubra. It is classified as an ionophor and predominantly used as an anticoccidial agent, which is mixed with poultry feed in the ratio of 5 ppm. ${ }^{1}$ There are numerous observational and experimental reports to show that this compound, if used for a long time, can be toxic to the animals fed on this mixture..$^{2-6}$ However, toxicity data among humans inadvertently exposed to this compound has been lacking. We report seven victims with this unusual poisoning. We describe the protracted clinical course of one of these victims along with a tabulated description of the clinical course and relevant laboratory investigations of the others.

The index case was a 30 year old male poultry farm worker who was admitted to the medical emergency room of the Nehru Hospital of the Postgraduate Institute of Medical Education and Research, Chandigarh, India, after consuming a pudding of maduramicin mixed with vegetable oil, which he mistook for porridge under the influence of cannabis at a religious function. He had consumed this concoction in the company of six other friends. The approximate quantity of maduramicin ingested was $450 \mathrm{~g}$ in total. Within two hours, all seven victims developed vomiting and weakness of all four limbs and truncal muscles. Two victims died over the next 48 hours at the primary health centre where they were admitted and the others, including the index case, were referred to our hospital after eight days.

On arrival at our hospital, the index case complained of excessive sweating over the face and pain in the buttock area. On examination, the pulse rate was $80 /$ minute, respiratory rate of 16/minute, blood pressure of $120 / 80 \mathrm{mmHg}$, and excessive sweating over the face was noted. There was no pallor, icterus, cyanosis, or dependant oedema. The examination of the lungs, heart, and the abdomen was normal but the neurological examination showed a grade IV muscle power with generalised areflexia.

Upon investigation, the following were noted: the haemoglobin was $10 \mathrm{mmols} / \mathrm{L}$, total leucocyte counts $8.8 \times 10^{9} / \mathrm{L}$, and the differential counts and peripheral blood smears were normal. The serum biochemistry was normal and the electrocardiography, chest $x$ ray, ultrasound examination, and echocardiography were also normal. On day two of hospital admission, the pain in the buttock area and back worsened and the patient noted a darkening in the colour of the urine. Investigations revealed rhabdomyolysis (creatinine phosphokinase MM levels $17300 \mathrm{U} / \mathrm{L}$, serum myoglobin present, alanine aminotransminase $1.25 \mu \mathrm{kat} / \mathrm{L}$, and aspartate aminotransminase $0.60 \mu \mathrm{kat} / \mathrm{L}$ ) following which alkalinisation of the urine was started. Over the next four days, hyperkalaemia and acute renal failure set in and he had to be taken up for haemodialysis. The arterial blood gas analysis showed mild metabolic acidosis. By day six, the muscular weakness had become worse and involved the respiratory muscles as well. Nerve conduction studies showed a polyradiculopathy. He had to undergo endotracheal intubation for mechanical ventilation for four days and later a tracheotomy for airway support. The evolution of nosocomial pneumonia by day 10 necessitated the addition of broad spectrum antibiotics that resulted in clinical resolution of pneumonia. The muscle pain subsided three weeks after admission with clinical improvement and he was discharged on day 34 after admission in a stable condition.

Data from poultry animals, particularly chickens, have shown that certain species of animal coccidiodes-that is, Eimeria acervulina, E maxima, and E tenella-are responsible for malnutrition. Maduramicin is used admixed with chicken feed as an anti-cocciodial agent to prevent malnutrition before slaughtering for human consumption. Since the half life of this agent is 20-39 hours, its use in chicken feed is stopped five days before slaughter. ${ }^{1}$

Maduramicin acts by affecting cation transport across the cell membrane, increasing the influx of $\mathrm{Ca}^{+}, \mathrm{Na}^{+}$, and $\mathrm{K}^{+}$in the cell wall thereby causing cell membrane disruption and cell death. As an anti-microbial agent, maduramicin has a bactericidal action on many Gram positive bacteria and coccidiosis. Maduramicin is marketed as drug coated particles with particle size of $400 \mu$. The LD50 is $50 \mathrm{~g} /$ tonne of chicken feed and it is known as the most potent and toxic of all the ionophores. ${ }^{1}$ To the best of our knowledge, no known human toxicity has been reported.

Toxicity of maduramicin has been well documented in animals; in a herd of 277 beef breed calves, which were mistakenly given maduramicin in a total mixed ration, there was an acute toxicity with sudden death. ${ }^{2}$ Another report of the gross and histopathological lesions of 20 cattle, four sheep, one steer fed ad lib, six sheep dosed with toxic poultry litter, and ten sheep fed experimental rations of maduramicin showed that the macroscopic lesions in the cattle that died were indicative of congestive heart failure. ${ }^{3}$ On gross examination, the skeletal muscle of sheep, particularly the muscles of the hindquarters, appeared pale, oedematous, and mottled, which on microscopy showed granular degeneration with foci of necrosis and regeneration. One of the sheep in the poultry litter developed signs of congestive heart failure and the hearts of the other two were dilated. On cardiac histopathology, the lesions were more pronounced in cattle and comprised of varying degrees of atrophy, hypertrophy, degeneration, necrosis of myocardial fibres, and interstitial fibrosis. In the steer fed ad lib with this material, extensive hypertrophy and atrophy of myocardial fibres were evident. Other less evident microscopic lesions were diffuse hypertrophy of myocardial nuclei in all seven cases, myocardial fibre atrophy in six, multifocal fibrosis in six, necrosis in two 
Table 1 Comparison of clinical/pathological features of maduramicin toxicity in different species. ${ }^{2-6}$

\begin{tabular}{ll}
\hline Animal species & Clinical/pathological features \\
\hline Calves & Sudden cardiac death \\
Sheep & $\begin{array}{l}\text { Leg muscle weakness, myonecrosis, } \\
\text { cardiomyopathy, arrhythmias } \\
\text { Cardiac arrhythmias, heart failure, } \\
\text { Cartle, steer }\end{array}$ \\
cardiomyopathy \\
Chicken & Watery diarrhoea, macrocytic anaemia, \\
leucopoenia, lymphopenia & Muscle weakness, myonecrosis, acute renal \\
Humans & failure, polyneuropathy \\
\hline
\end{tabular}

cases, and focal endocardial thickening in two. This suggests that this form of maduramicin based poultry litter intoxication is chronic, the pathology of which is characterised by dilated cardiomyopathy with congestive heart failure and mild (cattle) to severe (sheep) skeletal muscle lesions. ${ }^{3}$

An experimental feeding trial was conducted in order to substantiate a hypothesis on the aetiology of cardiomyopathy in beef cattle in Israel. It was postulated that residues of the maduramicin in poultry litter fed to cattle were the cause of cardiomyopathy. The clinical, biochemical, necropsy, and histopathological findings showed that maduramicin is cardiotoxic to poultry litter. ${ }^{4}$ This finding has also been well documented in another experimental feeding trial from South Africa. ${ }^{5}$

Another study in chicken fed with maduramicin medicated feed at 5 and $10 \mathrm{ppm}$ for 21 days showed that it caused growth retardation. ${ }^{6}$ Clinical signs seen were watery diarrhoea, depression, dullness, and ruffled feathers in chickens from second week of the medication at $10 \mathrm{ppm}$, but these features were seen from the third week in the birds given maduramicin at $5 \mathrm{ppm}$. A macrocytic anaemia was evident in both the medicated groups. Leucopoenia because of lymphopenia was observed in the $10 \mathrm{ppm}$ group on day 21 . A comparison of the clinical features of toxicity in different species is given in table 1 . It is evident that the clinical toxicity of maduramicin in humans is very similar to that in sheep. Cardiotoxicity was not seen in any of our patients.
In our patients (table 2), maduramicin consumption caused very early manifestations of quadripareisis and death in two cases. In the index case, admitted at our hospital, the onset of polyradiculopathy and rhabdomyolysis with acute renal failure 8-10 days after the consumption were like those of a toxic neuromyopathic effect seen in animals, particularly sheep. All victims experienced a peculiar sweating over the facial region that could be attributed to an associated autonomic neuropathy caused by this agent as an accompaniment of toxic polyradiculopathy. Cardiomyopathy was not seen in any of the five victims admitted at our hospital. The variable clinical course of all subjects-with patients 1 and 2 succumbing to rhabdomyolysis and polyneuropathy, the index case having polyneuropathy with severe rhabdomyolysis and acute renal failure, and patients 3 and 4 having mild rhabdomyolysis-alone could be related to an interindividual differential sensitivity to the toxic effects or to an inequitable distribution of maduramicin in the pudding that was prepared. The fatal clinical course that occurred in victims 1 and 2 was in all probability related to the degree of rhabdomyolysis with hyperkalaemia, metabolic acidosis, and hypocalcaemia that set in very early after admission. The cause of death in victim 1 was attributed to hyperkalaemia and that of victim 2 to an acute onset of respiratory failure. In both the diseased victims the values of creatinine phosphokinase MM isoenzyme were markedly elevated when compared with the surviving victims.

In conclusion, of seven patients presenting with maduramicin toxicity, death occurred in four cases, a toxic polyneuropathy in four, a varying degree of rhabdomyolysis in five, and pigment induced acute renal failure in four of our patients.

\section{Authors' affiliations}

N Sharma, A Bhalla, S Varma, S Jain, S Singh, Department of Internal Medicine, Postgraduate Institute of Medical Education \& Research, Chandigarh - 160012, India

Competing interests: none declared

Correspondence to: Dr Navneet Sharma, Assistant Professor of Internal Medicine, Postgraduate Institute of Medical Education \& Research, Chandigarh - 160012, India; navneet_433@sify.com

Accepted for publication 5 January 2005

\begin{tabular}{|c|c|c|c|c|c|c|c|c|}
\hline Victim & $\begin{array}{l}\text { Facial sweating, } \\
\text { muscle pains, } \\
\text { and areflexia }\end{array}$ & $\begin{array}{l}\text { Serum K/ } \\
\text { Ca mmols/L }\end{array}$ & $\begin{array}{l}\text { CPK-MM } \\
\text { isoenzyme } \\
\mathrm{U} / \mathrm{L} \text { (normal = } \\
24-170 \mathrm{U} / \mathrm{L} \text { ) }\end{array}$ & $\begin{array}{l}\text { Renal } \\
\text { function } \\
\text { tests } \\
\mathrm{Ur} / \mathrm{Cr}\end{array}$ & $\begin{array}{l}\text { Serum } \\
\text { AST/ALT } \\
\mu \text { kat/L }\end{array}$ & $\begin{array}{l}\text { NCV } \\
\text { and } \\
\text { EMG }\end{array}$ & $\begin{array}{l}\mathrm{Blood} \\
\mathrm{pH} / \\
\mathrm{HCO}_{3}\end{array}$ & Outcome \\
\hline 1 & ++ & $6.2 / 2.0$ & 92200 & $\begin{array}{l}24.9 / \\
150\end{array}$ & $\begin{array}{l}1.28 / \\
1.57\end{array}$ & PN & $\begin{array}{l}7.25 / \\
16\end{array}$ & $\begin{array}{l}\text { Died } 24 \\
\text { hours after } \\
\text { admission }\end{array}$ \\
\hline 2 & + & $6.2 / 1.8$ & 163250 & $\begin{array}{l}12.5 / \\
100\end{array}$ & $\begin{array}{l}1.80 / \\
1.48\end{array}$ & PN & $\begin{array}{l}7.24 / \\
20\end{array}$ & $\begin{array}{l}\text { Died } 48 \\
\text { hours after } \\
\text { admission of } \\
\text { respiratory } \\
\text { failure }\end{array}$ \\
\hline 3 & + & $4.2 / 2.55$ & 230 & $\begin{array}{l}10.7 / \\
133\end{array}$ & $\begin{array}{l}0.17 / \\
0.17\end{array}$ & PN & $\begin{array}{l}7.36 / \\
22\end{array}$ & Survived \\
\hline 4 & + & $3.6 / 2.20$ & 769 & Normal & $\begin{array}{l}0.70 / \\
0.28\end{array}$ & Normal & $\begin{array}{l}7.42 / \\
24\end{array}$ & Survived \\
\hline
\end{tabular}

+ , mild symptoms; ++, severe symptoms; ALT, alanine aminotransaminase; AST, aspartate aminotransaminase; CPK-MM, creatinine phosphokinase $M M$ isoenzyme; $E M G$, electromyography; $\mathrm{HCO}_{3}$, serum bicarbonate in $\mathrm{mmols} / \mathrm{L} ; \mathrm{NCV}$, nerve conduction velocity; PN, polyneuropathy; Ser K/Ca, serum potassium/serum calcium; $\mathrm{Ur} / \mathrm{Cr}$, blood urea in $\mathrm{mmols} / \mathrm{L} /$ serum creatinine in $\mu \mathrm{mols} / \mathrm{L}$. 


\section{REFERENCES}

1 Reports of the Scientific Committee on Animal Nutrition (Seventh series, 1988). Commission of the European Communities. Agriculture. Report EUR $12824 \mathrm{EN}$. The use of maduramycin-ammonium in feedingstuffs for fattening chicken 1997:1-8.

2 Shlosberg A, Perl S, Harmelin A, et al. Acute maduramicin toxicity in calves. Vet Rec 1997; 140:643-6.

3 Bastianello SS, Fourie N, Prozesky L, et al. Cardiomyopathy of ruminants induced by the litter of poultry fed on rations containing the ionophore antibiotic, maduramicin. Macropathology and histopathology. Onderstepoort J Vet Res 1995;62:5-18.
4 Shlosberg A, Harmelin A, Perl S, et al. Cardiomyopathy in cattle induced by residues of the coccidiostat maduramicin in poultry litter given as a feedstuff. Vet Res Commun 1992;16:45-58.

5 Fourie N, Bastianello SS, Prozesky L, et al. Cardiomyopathy of ruminants induced by the litter of poultry fed on rations containing the ionophore antibiotic, maduramicin. I. Epidemiology, clinical signs and clinical pathology. Onderstepoort J Vet Res 1991:58:291-6.

6 Singh T, Gupta RP. Clinico-haematological and mineral studies on experimental maduramicin toxicity in chickens. Vet Parasitol $2003 ; 116: 345-53$.

\section{Clinical Evidence-Call for contributors}

Clinical Evidence is a regularly updated evidence-based journal available worldwide both as a paper version and on the internet. Clinical Evidence needs to recruit a number of new contributors. Contributors are healthcare professionals or epidemiologists with experience in evidence-based medicine and the ability to write in a concise and structured way.

Areas for which we are currently seeking contributors:

- Pregnancy and childbirth

- Endocrine disorders

- Palliative care

- Tropical diseases

We are also looking for contributors for existing topics. For full details on what these topics are please visit www.clinicalevidence.com/ceweb/contribute/index.jsp

However, we are always looking for others, so do not let this list discourage you.

Being a contributor involves:

- Selecting from a validated, screened search (performed by in-house Information Specialists) epidemiologically sound studies for inclusion.

- Documenting your decisions about which studies to include on an inclusion and exclusion form, which we keep on file.

- Writing the text to a highly structured template (about 1500-3000 words), using evidence from the final studies chosen, within 8-10 weeks of receiving the literature search.

- Working with Clinical Evidence editors to ensure that the final text meets epidemiological and style standards.

- Updating the text every 12 months using any new, sound evidence that becomes available. The Clinical Evidence in-house team will conduct the searches for contributors; your task is simply to filter out high quality studies and incorporate them in the existing text.

If you would like to become a contributor for Clinical Evidence or require more information about what this involves please send your contact details and a copy of your CV, clearly stating the clinical area you are interested in, to CECommissioning@bmigroup.com.

\section{Call for peer reviewers}

Clinical Evidence also needs to recruit a number of new peer reviewers specifically with an interest in the clinical areas stated above, and also others related to general practice. Peer reviewers are healthcare professionals or epidemiologists with experience in evidence-based medicine. As a peer reviewer you would be asked for your views on the clinical relevance, validity, and accessibility of specific topics within the journal, and their usefulness to the intended audience (international generalists and healthcare professionals, possibly with limited statistical knowledge). Topics are usually 1500-3000 words in length and we would ask you to review between 2-5 topics per year. The peer review process takes place throughout the year, and out turnaround time for each review is ideally 10-14 days.

If you are interested in becoming a peer reviewer for Clinical Evidence, please complete the peer review questionnaire at www.clinicalevidence.com/ceweb/contribute/peerreviewer.jsp 